\title{
Environmental Influences on Fish Species Distribution in the Musolo River System, Congo River Basin (Democratic Republic of the Congo, Central Africa)
}

\section{Tobit L. D. Liyandja, MSc}

Richard Gilder Graduate School at American Museum of Natural History, New York, USA. Department of Biology, Faculty of Sciences, University of Kinshasa, Kinshasa, Democratic Republic of Congo

Armel Ibala Zamba, PhD

Laboratory of Animal productions and Biodiversity, ENSAF, Marien Ngouabi University, Brazzaville, Republic of the Congo

\section{Channelle A. Sefu, BSc}

Didier L. Dianzuangani, BSc

Ready K. Konda, BSc

Raoul J. C. Monsembula Iyaba, PhD

Justin J. M. N. Mbimbi, PhD

Department of Biology, Faculty of Sciences,

University of Kinshasa, Kinshasa, Democratic Republic of Congo

Doi:10.19044/esj.2019.v15n33p192 URL:http://dx.doi.org/10.19044/esj.2019.v15n33p192

Abstract

Ichthyofaunal distribution was studied in the Musolo River system, a small affluent tributary of the Congo River flowing into Pool Malebo (Democratic Republic of the Congo). Twelve ecological stations were sampled, of which eight were located in the Musolo main-channel and four in the Fushi River, a principal tributary of the Musolo. Each station was sampled four times over a two-year period, with fishing techniques following standardized methods utilizing dip and cast nets, and nine environment variables were measured at each station. Fifty-three fish species belonging to 36 genera and 16 families were collected with the Alestidae, Distichodontidae, Cichlidae, Cyprinidae, Mormyridae, and Mochokidae being the most diversified. Redundancy Analysis with forward selection coupled with Monte Carlo permutation tests (499 permutations) identified total dissolved solid $(25.8 \%)$ and altitude $(24.4 \%)$ as accounting for $50.2 \%$ of total variance $(\mathrm{p}<0.05)$. The contribution of the two first axes was significant $(\mathrm{F}=3.41$; $\mathrm{p}=0.004)$. Species richness increases from upstream to downstream. In general, the high value of Shannon's diversity (1.07-2.67) and Equitability 
(0.62-0.96) indices at all sites, indicates that the examined stretch of the Musolo River system is in good ecological health, despite its location adjacent to the megacity of Kinshasa

Keywords: Fish, Ecology, Musolo River, Pool Malebo, Middle Congo, Africa

\section{Introduction}

Aquatic ecosystems throughout the African continent are increasingly impacted by human activities, such as over fishing and destructive fishing practices, charcoal production, industrial deforestation, dam construction for irrigation and hydropower, and pollution (Kamdem Toham \& Teugels, 1999; Mbimbi \& Stiassny, 2011; Aboua et al., 2015; Monsembula et al., 2013; Paugy \& Lévêque, 2017). The consequences of such activities potentially endanger the biological integrity of these ecosystems and the diversity of their ichthyofaunas. With almost 3.7 million $\mathrm{km}^{2}$ of drained surface, $40,200 \mathrm{~m}^{3} \mathrm{~s}^{-1}$ annual average discharge, and over 1250 valid fish species (Snoeks et al., 2011) the Congo basin, second only to the Amazon River in discharge (Lee et al., 2011), is not spared from human pressure, mainly amplified by rapid demographic growth and economic development. This huge area and its different aquatic habitats harbor the world's second most diversified freshwater fish community after that of the Amazon River basin (Winemiller et al., 2016).

Within the Congo Basin, Pool Malebo, which harbors about 316 fish species, forms the boundary between the lower and middle Congo ichthyofaunal regions and is one of the most species-rich areas currently known throughout the Congo catchment, exclusive of Lake Tanganyika (Snoeks et al., 2011). However, this species richness likely reflects the result of collection efforts mainly concentrated in the main channel of the Congo River and in some of its larger tributaries while smaller tributaries, such as the Musolo River, remain unexplored. Moreover, because of the demographic growth of the megacity of Kinshasa, smaller tributaries in the vicinity have undergone profound habitat alteration due to farming, deforestation, charcoal production, and overexploitation pressure. Thus, it is necessary to survey these smaller systems before species or populations go extinct because knowing how many and what species inhabit an ecosystem is fundamental for any ecological study and for effective management of biodiversity (Lalèyé 2006; Olds et al., 2016).

To contribute to the knowledge of diversity and ecology of the Congo basin ichthyofauna, the present study was conducted in the Musolo River basin where diversity and spatial distribution of fish species was investigated, and the main environmental variables associated with species assemblages were assessed. 


\section{Material and Methods \\ Study area}

Fishes were collected in the Musolo River system, including the mainchannel and Fushi River, its principal tributary (Figure 1). With a mainchannel length of around $20 \mathrm{~km}$, and a basin area of about $120 \mathrm{~km}^{2}$, the Musolo River is a small left bank tributary of the Congo River flowing into Pool Malebo in the Democratic Republic of the Congo. The Musolo River system is located in N'sele, a peripheral municipality of the megacity of Kinshasa, at about $25 \mathrm{~km}$ from the center of Kinshasa. Nowadays, about 15 percent of the Musolo drainage is located within the heavily populated port town of Kinkole in the northeast part of the city.

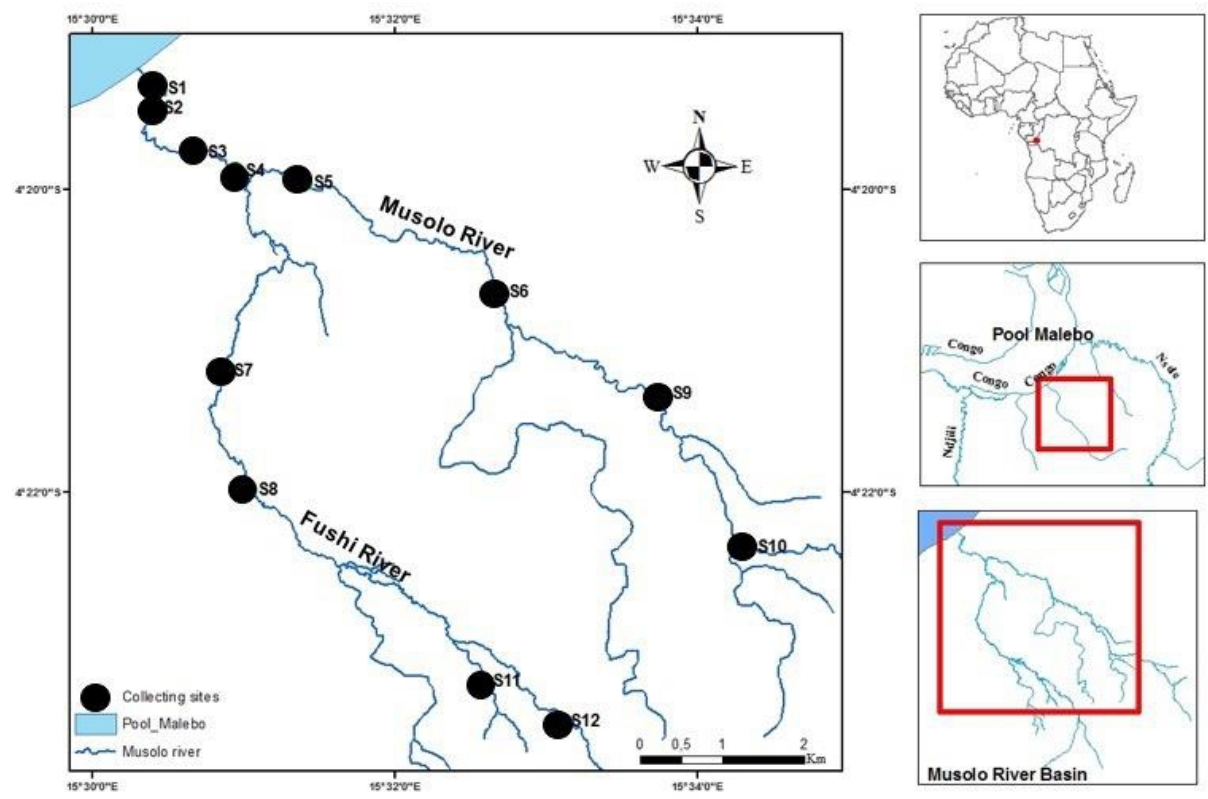

Figure 1: Musolo River basin and sampling stations

\section{Fish sampling}

A total of 12 ecological stations were sampled (Figure 1) eight of which (S 1, 2, 3, 4, 5, 6, 9 and 10) located in the main-channel and four (S 7, 8, 11 and 12) located in a major tributary (Figure 1). Stations were sampled four times over a two-year period from February 2015 through September 2016, including both the dry and rainy seasons. Standardized fishing techniques utilized dip nets and cast nets of $12 \mathrm{~mm}$ mesh size and $3 \mathrm{~m}$ in diameter. At each station of about $100 \mathrm{~m}$, three dip nets were used (Figure 2a) simultaneously during $30 \mathrm{~min}$ before making 20 cast net jets along the length of each station (Figure 2b).

All samples were identified in the field, specimens counted by species and tissue samples were taken from vouchered specimens for DNA extraction 
to be analyzed in subsequent studies. Fishes for which field identification was not certain were preserved in $10 \%$ formalin for subsequent identification in the laboratory of the Ichthyology Department of the American Museum of Natural History (AMNH). The classification of the families follows Van Der Laan et al (2019), with genera and species in alphabetical order.

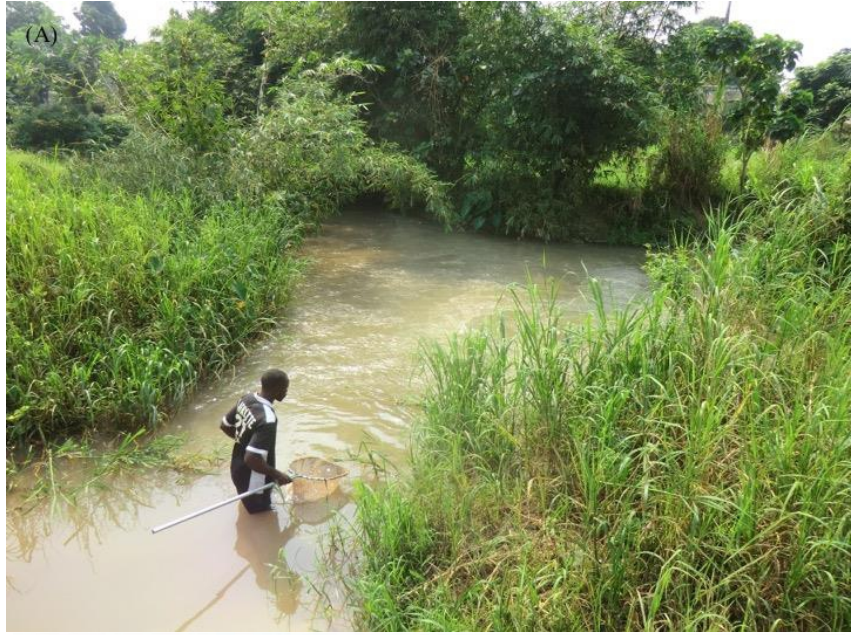

(B)

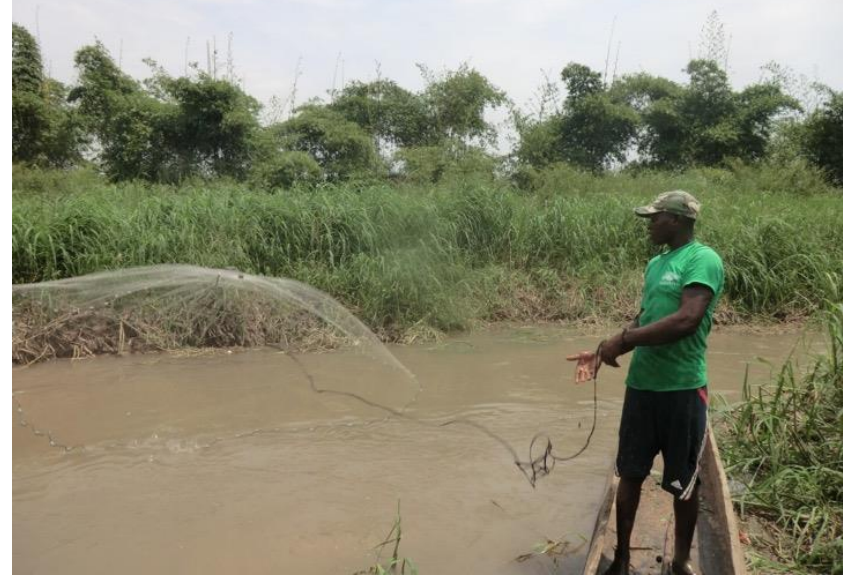

Figure 2: Fishing technics. a: search with dip nets (station 4); b: cast nets (station 1).

\section{Environmental data}

Prior to fish sampling, nine environmental parameters were collected at each station (Table 1). The variables included are: depth (in m, measured with a Norcross Hawkeye H22PX echo-sounder); $\mathrm{pH}$, water temperature (in ${ }^{\circ} \mathrm{C}$ ), total dissolved solid (in ppm), and conductivity $(\mu \mathrm{S} / \mathrm{cm}$ ) (all measured with a Hanna Combo tester HI 98129); altitude (measured in $\mathrm{m}$ with a GPSmap 64st). The following substrate categories were identified and scored as \%: sand; mud; and gravel. Data for all nine parameters were collected at the beginning, middle, and end of each station. Therefore, for each station, values 
given are mean values for 3 sampling points, 2 seasons and 2 years (total $\mathrm{N}=$ 12).

Table 1: Physico-chemical characteristics measured. *: 3 sampling points, 2 seasons and 2 years $($ total $N=12)$

\begin{tabular}{|c|c|c|c|c|c|c|c|c|c|c|c|c|c|}
\hline \multirow{2}{*}{$\begin{array}{c}\text { Environmental } \\
\text { variables }\end{array}$} & \multirow{2}{*}{ Code } & \multicolumn{12}{|c|}{ Stations } \\
\hline & & S1 & S2 & S3 & S4 & S5 & S6 & S7 & S8 & S9 & S10 & S11 & S12 \\
\hline Temperature $\left({ }^{\circ} \mathrm{C}\right)^{*}$ & Temp & 27.6 & 30 & 27.3 & 26.2 & 27.5 & 30.1 & 28.1 & 28.4 & 26 & 26 & 24 & 24.2 \\
\hline $\mathrm{pH}^{*}$ & $\mathrm{PH}$ & 5.9 & 5.75 & 6.09 & 6.1 & 6.75 & 6.18 & 5.9 & 6 & 6.2 & 6.1 & 5.93 & 6.25 \\
\hline $\begin{array}{c}\text { Conductivity } \\
(\mu \mathrm{S} / \mathrm{cm})^{*} \\
\text { Total Dissolved }\end{array}$ & Con & 6.0 & 4.0 & 5.0 & 5.0 & 3.0 & 1.0 & 1.0 & 2.0 & 2.0 & 2.0 & 6.0 & 5.0 \\
\hline Solids (ppm)* & TDS & 3.0 & 2.0 & 2.0 & 2.0 & 1.0 & 1.0 & 1.0 & 1.0 & 1.0 & 1.0 & 3.0 & 2.0 \\
\hline Altitude (m) & Alt & 280 & 281 & 282 & 287 & 289 & 313 & 300 & 309 & 328 & 359 & 327 & 338 \\
\hline Depth $(\mathrm{m})^{*}$ & Dep & 0.7 & 1.3 & 1.1 & 1.2 & 0.9 & 0.8 & 1.2 & 1 & 0.5 & 0.5 & 0.5 & 0.8 \\
\hline Substrate types (\%) & & & & & & & & & & & & & \\
\hline Sand & San & 80 & 100 & 100 & 100 & 80 & 100 & 100 & 100 & 100 & 100 & 60 & 80 \\
\hline Mud & Mud & 20 & 0 & 0 & 0 & 20 & 0 & 0 & 0 & 0 & 0 & 40 & 0 \\
\hline Gravel & Gra & 0 & 0 & 0 & 0 & 0 & 0 & 0 & 0 & 0 & 0 & 0 & 20 \\
\hline
\end{tabular}

\section{Data analysis}

In the present study, Redundancy Analysis (RDA), using CANOCO (Canonical Community Ordination, version 4.5) (Ter Braak \& Šmilauer, 2003) was used to investigate possible correlations between environmental variables and fish community assemblages. Therefore, two matrices covering the 12 sampling stations were constructed: (1) numerical abundance of all species collected and (2) environmental variables. Monte Carlo tests (499 permutations, $\mathrm{p}<0.05)$ were used to select environmental variables explaining variation in the fish species data. Prior to ordination, fish abundance and environmental data were transformed to better meet the assumptions of normality (Fischer \& Paukert, 2008) using respectively $\log _{10}(\mathrm{x}+1)$ and $\ln$ $(\mathrm{x}+1)$ or $\operatorname{ArcSin} \sqrt{\mathrm{x}}$ for percentages.

The ecological health of the Musolo River was evaluated at each station by calculating three ecological diversity indices (Lobry et al., 2003; Lande, 1996), using PRIMER version 5 (Clarke \& Gorley, 2001): Species richness S, Shannon index H', and Equitability R. Species richness S is the number of species represented in the catches. Shannon diversity index H' (Shannon, 1948) was calculated according to the following formula:

$$
\mathrm{H}^{\prime}=-\sum_{i=1}^{\mathrm{S}} \mathrm{P}_{i} \ln \mathrm{P}_{i}
$$

With $\mathrm{P}_{i}=\mathrm{n}_{i} / \mathrm{N} ; \mathrm{N}$ being the total number of individuals obtained for all species, $\mathrm{n}_{\mathrm{i}}$ is the number of individuals of species $i$ and $\mathrm{P}_{i}$ the relative abundance of species $i$ in the sample. Shannon index varies between 0 and H' maximum, calculated according to the formula: 


$$
\mathrm{H}^{\prime} \max .=\ln \mathrm{S} \text {. }
$$

The Equitability R (Pielou, 1966) indicates whether individuals are equally distributed among the species of the studied site, and varies between 0 and 1. It tends towards 0 when the totality of catches is almost entirely of one species, and towards 1 when all species have the same abundance within given sample. It is calculated using the formula:

$$
\mathrm{R}=\mathrm{H}^{\prime} / \mathrm{H}^{\prime} \max \text {. }
$$

\section{Results \\ Species composition}

The composition of the ichthyofauna of the Musolo River system collected during this study is presented in Table 2. A total of 602 specimens, including 53 species belonging to 36 genera and 16 families, were collected. The species reported, include two Clariallabes unassignable to currently known species and one introduced species (Oreochromis niloticus). Among the fish families sampled, Alestidae ( $\mathrm{n}=8$ species), Distichodontidae $(\mathrm{n}=7)$, Cichlidae, Cyprinidae, and Mormyridae $(n=6$ each), Mochokidae $(n=4)$ are the six most represented. The remaining families are poorly represented $(1 \leq$ $\mathrm{n} \leq 3)$. 
Table 2: List of species collected, their code and relative abundance. $(*)$ Introduced species.

\begin{tabular}{|c|c|c|c|c|c|c|c|c|c|c|c|c|c|}
\hline Families and species & Code & S1 & $\mathbf{S 2}$ & $\mathbf{S 3}$ & S4 & $\mathbf{S 5}$ & S6 & S7 & S8 & S9 & $\mathbf{S 1 0}$ & S11 & $\mathbf{S 1 2}$ \\
\hline \multicolumn{14}{|l|}{ Notopteridae } \\
\hline Xenomystus nigri (Günther, 1868) & Xen & 0.0 & 0.0 & 0.0 & 0.0 & 0.0 & 0.0 & 0.0 & 0.0 & 0.0 & 0.0 & 4.4 & 0.0 \\
\hline \multicolumn{14}{|l|}{ Mormyridae } \\
\hline Gnathonemus petersii (Günther, 1862) & Gnp & 1.2 & 0.0 & 1.8 & 1.7 & 0.0 & 0.0 & 0.0 & 0.0 & 0.0 & 0.0 & 0.0 & 0.0 \\
\hline Marcusenius aff. macrolepidotus (Peters, 1852) & Mam & 5.8 & 3.4 & 0.0 & 3.4 & 0.0 & 0.0 & 0.0 & 0.0 & 0.0 & 0.0 & 0.0 & 0.0 \\
\hline Marcusenius monteiri (Günther, 1873) & Mamo & 0.0 & 5.2 & 0.0 & 0.0 & 0.0 & 0.0 & 0.0 & 0.0 & 0.0 & 0.0 & 0.0 & 0.0 \\
\hline Marcusenius stanleyanus & Mas & 0.8 & 0.0 & 0.0 & 0.0 & 0.0 & 0.0 & 0.0 & 0.0 & 0.0 & 0.0 & 0.0 & 0.0 \\
\hline Petrocephalus christyi Boulenger, 1920 & Pec & 0.4 & 0.0 & 0.0 & 0.0 & 0.0 & 0.0 & 0.0 & 0.0 & 0.0 & 0.0 & 0.0 & 0.0 \\
\hline Petrocephalus microphthalmus Pellegrin, 1908 & Pem & 0.8 & 0.0 & 0.0 & 0.0 & 0.0 & 0.0 & 0.0 & 0.0 & 0.0 & 0.0 & 0.0 & 0.0 \\
\hline Clupeidae & & & & & & & & & & & & & \\
\hline Microthrissa congicus (Regan, 1917) & Mic & 2.1 & 0.0 & 0.0 & 0.0 & 0.0 & 0.0 & 0.0 & 0.0 & 0.0 & 0.0 & 0.0 & 0.0 \\
\hline \multicolumn{14}{|l|}{ Cyprinidae } \\
\hline Clypeobarbus pleuropholis (Boulenger, 1899) & Clp & 15.4 & 0.0 & 0.0 & 0.0 & 0.0 & 0.0 & 0.0 & 0.0 & 0.0 & 0.0 & 0.0 & 0.0 \\
\hline Labeo lineatus Boulenger, 1898 & Lali & 2.5 & 0.0 & 3.6 & 1.7 & 0.0 & 0.0 & 0.0 & 0.0 & 0.0 & 0.0 & 0.0 & 0.0 \\
\hline Labeo longipinnis Boulenger, 1898 & Lalo & 0.0 & 1.7 & 0.0 & 0.0 & 0.0 & 0.0 & 0.0 & 0.0 & 0.0 & 0.0 & 0.0 & 0.0 \\
\hline Labeo cf. parvus Boulenger, 1902 & Lap & 0.0 & 0.0 & 0.0 & 1.7 & 4.5 & 0.0 & 0.0 & 0.0 & 0.0 & 0.0 & 0.0 & 0.0 \\
\hline Labeo weeksii Boulenger, 1909 & Law & 1.2 & 0.0 & 1.8 & 5.2 & 4.5 & 21.1 & 9.1 & 0.0 & 0.0 & 0.0 & 0.0 & 0.0 \\
\hline Raiamas christyi (Boulenger, 1920) & $\operatorname{Rac}$ & 0.8 & 12.1 & 7.3 & 3.4 & 54.5 & 42.1 & 72.7 & 23.1 & 46.9 & 0.0 & 0.0 & 24.0 \\
\hline \multicolumn{14}{|l|}{ Distichodontidae } \\
\hline Distichodus affinis Günther, 1873 & Diaf & 0.0 & 1.7 & 0.0 & 0.0 & 0.0 & 0.0 & 0.0 & 0.0 & 0.0 & 0.0 & 0.0 & 0.0 \\
\hline Distichodus antonii Schilthuis, 1891 & Dian & 0.4 & 3.4 & 0.0 & 0.0 & 0.0 & 0.0 & 0.0 & 0.0 & 0.0 & 0.0 & 0.0 & 0.0 \\
\hline Distichodus atroventralis Boulenger, 1898 & Diat & 0.0 & 1.7 & 1.8 & 0.0 & 0.0 & 0.0 & 0.0 & 0.0 & 0.0 & 0.0 & 0.0 & 0.0 \\
\hline Distichodus sexfasciatus Worthington \& Ricardo, 1937 & Dis & 0.4 & 1.7 & 0.0 & 0.0 & 0.0 & 0.0 & 0.0 & 0.0 & 0.0 & 0.0 & 0.0 & 0.0 \\
\hline Mesoborus crocodilus Pellegrin, 1900 & Mec & 0.8 & 0.0 & 0.0 & 0.0 & 0.0 & 0.0 & 0.0 & 0.0 & 0.0 & 0.0 & 0.0 & 0.0 \\
\hline Nannocharax cf. gracilis Poll, 1939 & Nag & 0.4 & 0.0 & 0.0 & 0.0 & 0.0 & 0.0 & 0.0 & 0.0 & 0.0 & 0.0 & 0.0 & 0.0 \\
\hline Nannocharax cf. schoutedeni Poll, 1939 & Nas & 0.4 & 0.0 & 0.0 & 1.7 & 0.0 & 0.0 & 0.0 & 0.0 & 0.0 & 0.0 & 0.0 & 0.0 \\
\hline
\end{tabular}


Table 2: Continued.

\begin{tabular}{|c|c|c|c|c|c|c|c|c|c|c|c|c|c|}
\hline Families and species & Code & S1 & S2 & S3 & S4 & $\mathbf{S 5}$ & S6 & S7 & S8 & S9 & $\mathbf{S 1 0}$ & $\mathbf{S 1 1}$ & S12 \\
\hline \multicolumn{14}{|l|}{ Alestidae } \\
\hline Alestopetersius tumbensis Hoedeman, 1951 & Alt & 2.9 & 0.0 & 0.0 & 0.0 & 0.0 & 0.0 & 0.0 & 0.0 & 0.0 & 0.0 & 0.0 & 0.0 \\
\hline Brycinus comptus (Roberts \& Stewart, 1976) & Brc & 22.8 & 8.6 & 30.9 & 12.1 & 0.0 & 0.0 & 0.0 & 0.0 & 0.0 & 0.0 & 0.0 & 0.0 \\
\hline Brycinus imberi (Peters, 1852) & Bri & 0.0 & 1.7 & 0.0 & 0.0 & 0.0 & 0.0 & 0.0 & 0.0 & 0.0 & 0.0 & 0.0 & 0.0 \\
\hline Bryconaethiops boulengeri Pellegrin, 1900 & Brb & 0.0 & 0.0 & 0.0 & 0.0 & 0.0 & 0.0 & 4.5 & 0.0 & 18.8 & 0.0 & 0.0 & 12.0 \\
\hline Hydrocynus goliath Boulenger, 1898 & Hyg & 0.4 & 0.0 & 0.0 & 0.0 & 0.0 & 0.0 & 0.0 & 0.0 & 0.0 & 0.0 & 0.0 & 0.0 \\
\hline Hydrocynus vittatus Castelnau, 1861 & Hyv & 0.4 & 0.0 & 0.0 & 0.0 & 0.0 & 0.0 & 0.0 & 0.0 & 0.0 & 0.0 & 0.0 & 0.0 \\
\hline Micralestes acutidens (Peters, 1852) & Mia & 19.5 & 3.4 & 3.6 & 0.0 & 0.0 & 0.0 & 0.0 & 0.0 & 0.0 & 0.0 & 0.0 & 0.0 \\
\hline Phenacogrammus interruptus (Boulenger, 1899) & Phi & 3.7 & 22.4 & 0.0 & 0.0 & 0.0 & 0.0 & 0.0 & 0.0 & 0.0 & 0.0 & 0.0 & 0.0 \\
\hline \multicolumn{14}{|l|}{ Clariidae } \\
\hline Clariallabes sp1 & Clsp1 & 0.0 & 0.0 & 0.0 & 0.0 & 0.0 & 0.0 & 0.0 & 0.0 & 6.3 & 0.0 & 2.2 & 0.0 \\
\hline Clariallabes sp2 & Clsp2 & 0.4 & 0.0 & 0.0 & 6.9 & 0.0 & 0.0 & 0.0 & 0.0 & 0.0 & 0.0 & 0.0 & 0.0 \\
\hline Clarias gabonensis Günther, 1867 & $\mathrm{Clg}$ & 0.0 & 1.7 & 0.0 & 0.0 & 0.0 & 0.0 & 0.0 & 0.0 & 0.0 & 0.0 & 0.0 & 0.0 \\
\hline \multicolumn{14}{|l|}{ Amphiliidae } \\
\hline Belonoglanis tenuis Boulenger, 1902 & Beb & 1.7 & 8.6 & 43.6 & 36.2 & 0.0 & 0.0 & 0.0 & 0.0 & 0.0 & 0.0 & 0.0 & 0.0 \\
\hline Phractura scaphyrhynchura (Vaillant, 1886) & Phs & 0.0 & 0.0 & 0.0 & 0.0 & 0.0 & 0.0 & 0.0 & 0.0 & 6.3 & 0.0 & 0.0 & 0.0 \\
\hline \multicolumn{14}{|l|}{ Mochokidae } \\
\hline Microsynodontis christyi Boulenger, 1920 & Mich & 0.8 & 0.0 & 0.0 & 0.0 & 0.0 & 0.0 & 0.0 & 0.0 & 0.0 & 0.0 & 0.0 & 0.0 \\
\hline Synodontis congica Poll, 1971 & Syc & 0.0 & 6.9 & 0.0 & 8.6 & 0.0 & 0.0 & 0.0 & 0.0 & 0.0 & 0.0 & 0.0 & 0.0 \\
\hline Synodontis notatus Vaillant, 1893 & Syn & 0.8 & 0.0 & 3.6 & 0.0 & 0.0 & 0.0 & 0.0 & 0.0 & 0.0 & 0.0 & 0.0 & 0.0 \\
\hline Synodontis schoutedeni David, 1936 & Sys & 0.8 & 3.4 & 0.0 & 0.0 & 0.0 & 0.0 & 0.0 & 0.0 & 0.0 & 0.0 & 0.0 & 0.0 \\
\hline
\end{tabular}




\section{Clroteidae}

Auchenoglanis occidentalis (Valenciennes, 1840)

Auo

Parauchenoglanis monkei (Keilhack, 1910)

Families and species

Pam

$\begin{array}{lll}0.8 & 0.0 & 0.0\end{array}$

0.0

$0.0 \quad 0.0$

$\begin{array}{ll}0.0 & 0.0\end{array}$

0.0

$0.0 \quad 0.0$

Table 2: Continued.

\section{Schilbeidae}

Parailia congica Boulenger, 1899

Schilbe intermedius Rüppell, 1832

Schilbe marmoratus Boulenger, 1911

\begin{tabular}{lllllllllllll} 
Code & S1 & S2 & S3 & S4 & S5 & S6 & S7 & S8 & S9 & S10 & S11 & S12 \\
\hline
\end{tabular}

\section{Mastacembelidae}

Mastacembelus niger (Sauvage, 1879)

\section{Channidae}

Parachanna obscura (Günther, 1861)

\section{Cichlidae}

Coptodon tholloni (Sauvage, 1884)

Ctenochromis polli (Thys van den Audenaerde, 1964)

Hemichromis elongatus (Guichenot, 1861)

Hemichromis stellifer Loiselle. 1979

$\begin{array}{ccccccccccccc}\text { Pac } & 0.4 & 0.0 & 0.0 & 0.0 & 0.0 & 0.0 & 0.0 & 0.0 & 0.0 & 0.0 & 0.0 & 0.0 \\ \text { Sci } & 2.5 & 1.7 & 1.8 & 12.1 & 0.0 & 0.0 & 0.0 & 0.0 & 0.0 & 0.0 & 0.0 & 0.0 \\ \text { Scm } & 0.8 & 0.0 & 0.0 & 0.0 & 0.0 & 0.0 & 0.0 & 0.0 & 0.0 & 0.0 & 0.0 & 0.0\end{array}$

Oreochromis niloticus (Linneaus, 1758)*

Tylochromis lateralis (Boulenger, 1898)

\section{Nothobranchiidae}

Epiplatys chevalieri (Pellegrin, 1904)

\begin{tabular}{ccccccccccccc} 
Man & 0.0 & 1.7 & 0.0 & 0.0 & 0.0 & 0.0 & 0.0 & 0.0 & 3.1 & 0.0 & 0.0 & 0.0 \\
& & & & & & & & & & & & \\
Pao & 0.0 & 1.7 & 0.0 & 0.0 & 0.0 & 0.0 & 0.0 & 0.0 & 0.0 & 0.0 & 2.2 & 0.0 \\
& & & & & & & & & & & & \\
Cot & 2.1 & 5.2 & 0.0 & 1.7 & 0.0 & 0.0 & 0.0 & 0.0 & 0.0 & 0.0 & 40.0 & 52.0 \\
Ctp & 0.4 & 0.0 & 0.0 & 0.0 & 0.0 & 0.0 & 0.0 & 0.0 & 0.0 & 0.0 & 0.0 & 0.0 \\
Hee & 1.2 & 1.7 & 0.0 & 0.0 & 4.5 & 5.3 & 0.0 & 0.0 & 0.0 & 50.0 & 6.7 & 0.0 \\
Hes & 1.7 & 0.0 & 0.0 & 0.0 & 31.8 & 26.3 & 13.6 & 23.1 & 6.3 & 16.7 & 28.9 & 8.0 \\
Orn & 1.2 & 0.0 & 0.0 & 0.0 & 0.0 & 0.0 & 0.0 & 0.0 & 0.0 & 0.0 & 0.0 & 0.0 \\
Tyl & 0.8 & 0.0 & 0.0 & 0.0 & 0.0 & 0.0 & 0.0 & 0.0 & 0.0 & 0.0 & 0.0 & 0.0 \\
& & & & & & & & & & & & \\
Epc & 0.0 & 0.0 & 0.0 & 0.0 & 0.0 & 5.3 & 0.0 & 15.4 & 12.5 & 33.3 & 15.6 & 0.0 \\
Eps & 0.0 & 0.0 & 0.0 & 3.4 & 0.0 & 0.0 & 0.0 & 38.5 & 0.0 & 0.0 & 0.0 & 0.0 \\
\hline
\end{tabular}




\section{Fish communities, stations and environmental variables}

Results of the Redundancy Analysis (Figure 3) indicate that the first two axes (33.3\% and $9.8 \%$ respectively) express $43.1 \%$ of the cumulative variance in the fish data. Species and environmental variable correlations for both axes are high, respectively 0.88 and 0.84 . Monte Carlo permutation tests (499 iterations) also indicate that the contributions of the two first axes are significant $(\mathrm{F}=3.41 ; \mathrm{p}=0.004)$. Redundancy Analysis with forward selection identified two environmental variables as accounting for $50.2 \%$ of the total variance among five variables ( $\mathrm{p}<0.05$ ): total dissolved solids (TDS, 25.8\%) and altitude (24.4\%). Our results indicate that these two environmental variables have a significant $(\mathrm{p}<0.05)$ influence on fish community assemblages in the Musolo River basin.

Three habitat types of sampling sites are distinguished in relation to both RDA Axes 1 and 2 (see Figure 3a): Upstream, represented by sites located upstream close to the source (S9, S10, S11 and S12); Middle, sites composed of intermediate stations (S5, S6, S7and S8); and downstream, composed of sites ( $1, S 2, \mathrm{~S} 3$ and $\mathrm{S} 4)$ situated downstream from the confluence of the Musolo River main-channel with the Fushi River.

The main fish species found upstream, positively correlated with Axis 2 are Bryconaethiops boulengeri, Clariallabes sp1, Coptodon tholloni, Epiplatys chevalieri, E. spilargyreius, Hemichromis elongatus, H. stellifer, Parauchenoglanis monkei, and Xenomystus nigri. Intermediate habitats, positively correlated with Axe 1 and negatively correlated with Axis 2, are mainly composed of Brycinus comptus, Clarias gabonensis, Labeo longipinnis, Mastacembelus niger, Phractura scaphyrhynchura, Raiamas christyi. Downstream habitats, negatively correlated with Axis 1, are distinguished by an assemblage including Alestopetersius tumbensis, Auchenoglanis occidentalis, Belonoglanis tenuis, Brycinus imberi, Clariallabes sp2, Clypeobarbus pleuropholis, Ctenochromis polli, Distichodus affinis, Distichodus antonii, D. atroventralis, D. sexfasciatus, Gnathonemus petersii, Hydrocynus goliath, H. vittatus, Labeo lineatus, L. cf. parvus, L. weeksii, Marcusenius aff. macrolepidotus, M. monteiri, $M$. stanleyanus, Mesoborus crocodilus, Micralestes acutidens, Microthrissa congicus, Microsynodontis christyi, Nannocharax cf. schoutedeni, N. cf. gracilis, Oreochromis niloticus, Parachanna obscura, Parailia congica, Petrocephalus christyi, P. microphthalmus, Phenacogrammus interruptus, Schilbe intermedius, S. marmoratus, Synodontis congica, S. notatus, $S$. schoutedeni and Tylochromis lateralis. 

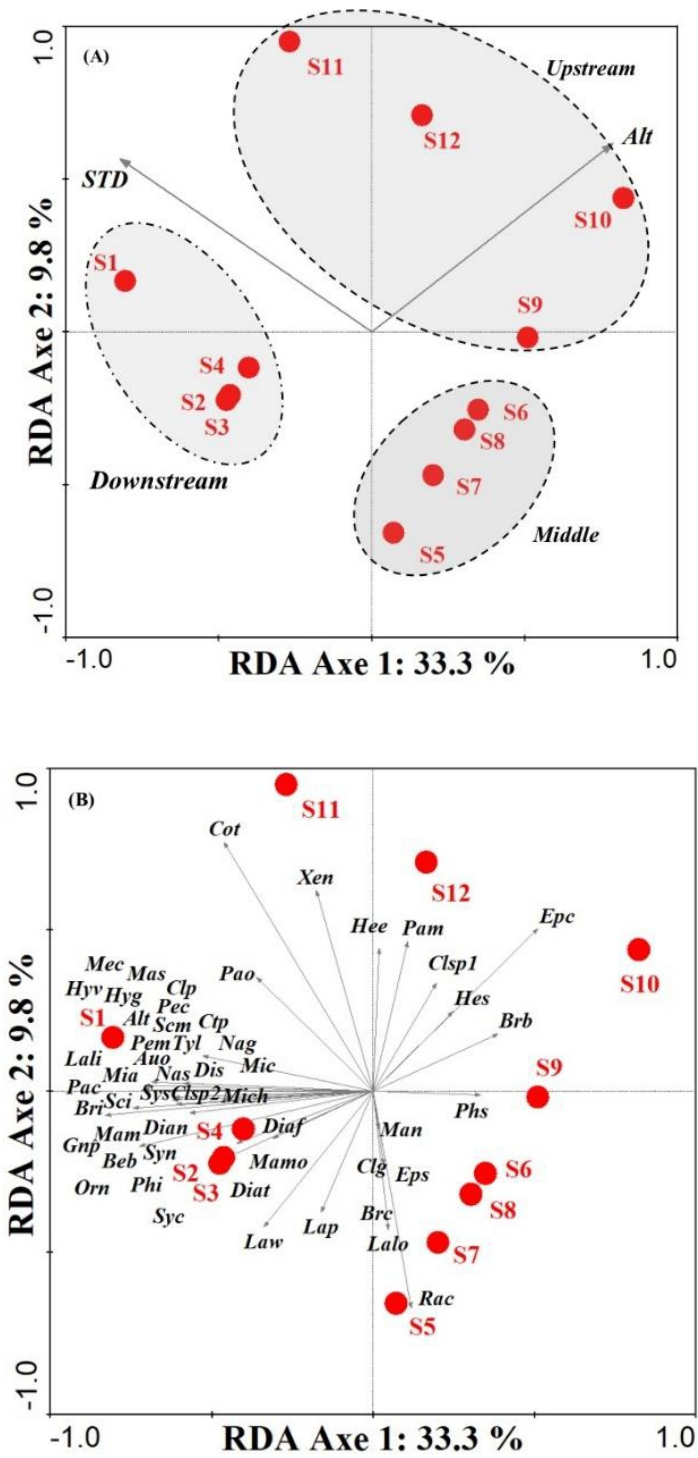

Figure 3: Redundancy Analysis ordination of species, stations, and the two forward selected environmental variables. A: biplot of stations and environment variables; B: biplot of stations and species.

\section{Spatial variation of ecological diversity indices}

For each of the twelve sampling stations, diversity indices, including species richness (S), Shannon index (H'), Shannon maximum index (H' max.), and Equitability (R) were calculated (Table 3). With 12 specimens and three species, station 10 was the least diversified, whereas station 1 was the most diversified with 241 specimens and 36 species. However, values of Equitability were highest 0.96 in station 8 and lowest 0.62 in station 7 . 
Table 3: Ecological diversity indices. $N$ : number of specimens; $S$ : Species richness; $H^{\prime}$ : Shannon index; H'max.: Shannon maximum index; R: Equitability.

\begin{tabular}{cccccc} 
Stations & S & $\mathbf{N}$ & $\mathbf{R}$ & $\mathbf{H}^{\prime}$ & H'max \\
\hline S1 & 36 & 241 & 0.74 & 2.66 & 3.58 \\
S2 & 21 & 58 & 0.88 & 2.67 & 3.04 \\
S5 & 6 & 23 & 0.70 & 1.25 & 1.79 \\
S6 & 5 & 19 & 0.84 & 1.35 & 1.61 \\
S7 & 4 & 22 & 0.62 & 0.86 & 1.39 \\
S8 & 4 & 13 & 0.96 & 1.33 & 1.39 \\
S4 & 14 & 58 & 0.81 & 2.13 & 2.64 \\
S3 & 10 & 55 & 0.70 & 1.57 & 2.30 \\
S9 & 7 & 32 & 0.80 & 1.56 & 1.95 \\
S10 & 3 & 12 & 0.92 & 1.01 & 1.10 \\
S11 & 8 & 46 & 0.76 & 1.57 & 2.08 \\
S12 & 5 & 25 & 0.79 & 1.27 & 1.61 \\
\hline
\end{tabular}

\section{Discussion}

Considering the small size of the Musolo River catchment (c. $\left.120 \mathrm{~km}^{2}\right)$ and sampling following standardized methods utilizing only dip nets and cast nets, a total of 53 species is unexpectedly high, particularly in comparison with the considerably larger nearby Congo tributaries such as N'sele $\left(6000 \mathrm{Km}^{2}\right)$, Inkisi $\left(13500 \mathrm{Km}^{2}\right)$ and Lefini $\left(13500 \mathrm{Km}^{2}\right)$ with respectively 148 species (Monsembula et al., 2013), 140 species (Ibala Zamba, 2010) and 61 species (Wamuini et al., 2010). The outflow of the Musolo River into Pool Malebo and the absence of rapids or waterfalls, which can act as barriers between these two ecosystems, likely accounts for the high species richness of the Musolo fish fauna by providing many opportunities for colonization to and from the Pool. That argument is supported by the fact that $98 \%$ of species reported from the Musolo River are also found in Pool Malebo (Brooks et al., 2011). Interestingly, Phractura scaphyrhynchura which was reported for the first time in the Kinshasa region by Monsembula et al. (2013) in a leftbank tributary

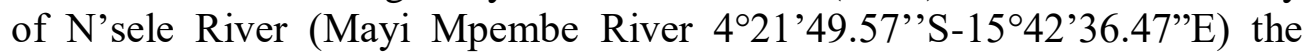
headwaters of which arise near headwaters of the Musolo River. The fact that Phractura scaphyrhynchura is present in both the Musolo River and the MayiMpembe River but absent in the Pool Malebo provides additional support for faunal exchange between neighbor catchments during periods of flooding or past stream capture in the Congo basin (Stiassny et al., 2016). The fish species reported in the present study are characteristic of the Congolese province (Lévêque, 1997), except for Orechromis nilotucus, which was introduced into this part of the Congo basin in 1957 for fish farming (Welcomme, 1988). In addition, a species composition dominated by Alestidae, Distichodontidae, Cichlidae, Cyprinidae, Mormyridae, and Mochokidae is in accord with the findings of Lévêque \& Paugy (2017a) for the Congo basin as a whole. 
The present study is one of the few ecological investigations of fishes performed within the Congo basin and complements a short list of the similar studies recently undertaken in the Inkisi River (Wamuini et al., 2010), a left bank affluent of the Congo River in the Democratic Republic of the Congo (DRC) and Lefini (Ibala Zamba et al., 2019), and Loua Rivers (Batiabo et al., 2019), respectively, a large and a small right bank affluent in the Republic of the Congo ( $\mathrm{RC}$ ). Indeed, investigations of the drivers of fish community assemblages, in general, are rarely performed in Africa (Kouamélan et al., 2003; Kouadio et al., 2006; Ibanez et al., 2007) and the few available studies have mostly been undertaken in West Africa (Mérona, 1981; Hugueny, 1989, 1990; Pouilly, 1993; Kouamélan et al., 2003; Yao et al., 2005; Kouadio et al., 2006, Aboua et al., 2015), South Africa (Hay et al., 1996) and in the Lower Guinean ichthyofaunal province (Kamdem Toham \& Teugels, 1997, 1998; Mbega, 2004; Ibaňez et al., 2007).

The standard observation of species richness increasing downstream (Hugueny, 1989, 1990; Paugy \& Bénech, 1989; Pouilly, 1993; Hay et al., 1996; Kamdem Toham \& Teugels, 1997, 1998; Kouamé et al., 2008) is reported here for the Musolo River system (see Figure 3b), even if, certainly because of the short length of the river $( \pm 20 \mathrm{~km})$ and human activities impacts, species numbers correlated with Upstream sites (9 species) is not significantly different from that reported in Middle sites (6). Indeed, according to Lévêque \& Paugy (2017b), the physical conditions found throughout a watercourse, from upstream to downstream, induces a response from biological communities, with a progressive change according to the capacities of species to adapt to environmental conditions and available food resources. This longitudinal zonation is accompanied by an increase in species richness through increasing habitat heterogeneity and volume (Hugueny, 1990).

Based on the RDA (Figure 3a), TDS (25.8\%) and slope $(24.4 \%)$ are the two most important variables for fish distribution in the Musolo basin. TDS, which is a measure of the combined dissolved content of all inorganic and organic inputs present in the water (Weber-Scannell \& Duffi, 2007), represents a variable strongly correlated with habitats downstream, likely explained by the fact that downstream sites are loaded with inputs from waters flowing from upstream. Therefore, in addition to the proximity to the Pool, elevated TDS probably also contributes to the high fish diversity of downstream sites ( $\mathrm{S}=38$ species vs. 9 and 6 , respectively in upstream and middle sites). However, the high slope (about $79 \mathrm{~m}$ ) between the most distant stations from upstream and those downstream, represented in the present study by the altitude, is also positively correlated with habitats situated upstream in the basin. In addition to this particularity, habitat homogeneity due to the proximity of these upstream habitats to the source would also undoubtedly contribute to their low fish diversity. 
Even if, studying fish communities using diversity indices does not reflect the organizational modalities of populations in a system (Barbault, 1992; Korkmaz \& Zencir, 2009), it is however known that these indices are of utility in the diagnosis of the ecological health of an aquatic ecosystem (Lobry et al., 2003; Daly et al., 2018). In the present study, three ecological diversity indices ( $\mathrm{S}, \mathrm{H}^{\prime}$ and $\mathrm{R}$ ) calculated based on species abundance, reveal that in all site as provided by the RDA (Figure 3a), the H' (Upstream: 1.98; Middle: mean $=1.47$; Downstream: 1.35) and R (Upstream: 0.79; Middle: mean = 0.77; Downstream: 0.82) indices are approaching their maximum values, respectively H' maximum $(2.50 ; 1.93 ; 1.69)$ for $H^{\prime}$ and 1 for $\mathrm{R}$. This reflects an excellent distribution of species abundance in the Musolo River basin, despite a weak evenness observed at station $7\left(\mathrm{H}^{\prime}=0.86 ; \mathrm{H}^{\prime} \max .=1.39\right.$. $\mathrm{R}$ $=0.62$ ), principally explained by the slight dominance of Raiamas christyi in the catches. Once again, this could likely be the result of the development of intense human activities around that habitat such as gardens, sand extraction, and charcoal production. According to Ludwig \& Reynolds (1988) and Lobry et al., (2003), when all species of the community have a good distribution of abundance and the environmental in good ecological health, H' and R indices approach their maximum values.

\section{Conclusion}

The present study contributes to a better understanding of fish communities in the Congo basin, by providing data on fish diversity and distribution in the Musolo River, one of its small left bank tributaries in the Democratic Republic of Congo. As in most of the Congo basin the ichthyofauna of Musolo River is diverse and Alestidae, Distichodontidae, Cichlidae, Cyprinidae, Mormyridae, and Mochokidae are the most represented families.

Total dissolved solids and altitude are shown to have a significant influence on the distribution of fish assemblages, and richness increases from upstream to downstream. The high value of Shannon and Equitability indices in all habitats sampled indicates that the Musolo basin is in good ecological health.

\section{Acknowledgement}

We would like to thank Melanie Stiassny for insightful comments on an earlier version of the manuscript; Barbara Brown, Radford Arrindell Tom Vigliotta, amd Chloe Lewis (AMNH) for help with the specimens housed in the collections under their care. The fieldwork of TLDL (2015-2016) and a study visit of AIZ to AMNH in 2019 were provided by the Axelrod Research Curatorship (MLJS). We are grateful to BEBUC, through Else-KronerFresenius-Stiftung foundation for their financial and moral support to TLDL. 
Finally, Heritier Lofongola and Norbert Muswambole are gratefully acknowledged for their companionship and assistance during field expeditions to the Musolo River.

\section{References:}

1. Aboua, B. R. D., N'zi, K. G., BAMBA, M. \& Kouamélan, E. P. (2015). Ichthyologic diversity of Bandama River basin (Côte d'Ivoire): an update and environmental influence on fish distribution. European Scientific Journal, 11(12), 99-116.

2. Barbault, R. (1992). Ecologie des peuplements, structure, dynamique et évolution. Masson, Paris.

3. Batiabo Mikembi, A. L, Ibala Zamba, A., Mamonekene, V., Poaty Ngot, H. F., Dembe Louvinguila Tenda, H. \& Vouidibio, J. (2019). Diversity and distribution of fish species along the Loua River, lower Congo River basin (Republic of the Congo, Central Africa). International Journal of Fisheries \& Aquatic Studies, 7(3), 171-176.

4. Brooks, E. G. E., Allen, D. J. \& Darwall, W. R. T. (2011). The Status and Distribution of Freshwater Biodiversity in Central Africa. Gland, Switzerland and Cambridge, UK: IUCN.

5. Clarke, K. R. \& Gorley, R. N. (2001). Primer v5: user manual/tutorial. Primer-E Ltd, Plymouth, UK.

6. Daly, A. J., Beatens, J. M \& De Beats B. 2018. Ecological Diversity: Measuring the Unmeasurable. Mathematics, 6, 119.

7. Fischer, J. R. \& Paukert, C. P. (2008). Habitat relationships with assemblages in minimally disturbed Great Plains regions. Ecology of Freshwater Fish, 17, 597-609.

8. Hay, C. J., Van Zyl, B. J. \& Steyn G. J. (1996). A quantitative assessment of biotic integrity of the Okavango river, Namibia based on fish. Water SA, 22, 263-284.

9. Hugueny, B. (1989). Biogéographie et structure des peuplements de poissons d'eau douce de l'Afrique de l'Ouest: approches quantitatives. Thèse Université Paris 7, 295 p.

10. Hugueny, B. (1990). Richesse des peuplements de poissons dans le Niandan (haut Niger, Afrique) en fonction de la taille de la rivière. Revue d'Hydrobiologie tropicale, 23(4), 351-364.

11. Ibala Zamba, A. (2010). Faune des poisons des rivières Luki et Lefini (Bassin du Congo): diversité et écologie. PhD thesis, KULeuven, Leuven-Belgium, $452 \mathrm{p}$.

12. Ibala Zamba, A., Mamonekene, V., Vreven, E. \& Snoeks, J. (2019). Fish community assemblages in relation to environmental variables in the Lefini River, middle Congo River basin (Republic of Congo). Cybium, 43(1), 83-95. 
13. Ibanez, C., Oberdorff, T., Teugels, G. G, Mamononekene, V., Lavoué, S., Fermon, Y., Paugy, D. \& Kamdem Toham, A. (2007). Fish assemblages structure and function along environmental gradients in rivers of Gabon (Africa). Ecology of Freshwater Fish, 16, 315-334.

14. Kamdem Toham, A. \& Teugels, G. G. (1997). Patterns of microhabitat use among fourteen abundant fishes of the lower Ntem River Basin (Cameroon). Aquatic Living Resources, 10(5), 289-298.

15. Kamdem Toham, A. \& Teugels, G. G. (1998). Diversity patterns of fish assemblages in the Lower Ntem River Basin (Cameroon), with notes on potential effects of deforestation. Archiv für Hydrobiologie, 141, 421-446.

16. Kamdem Toham, A. \& Teugels, G. G. (1999). First data on an index of biotic integrity (IBI) based on first assemblages for the assessment of the impact of the deforestation in a tropical West African river system. Hydrobiologia, 397, 29-38.

17. Korkmaz, A. S. \& Zencir, O. (2009). Fish community structure in Suveri stream, Central Antolia, Turkey. Journal of Animal and Veterinary Advances, 8(11), 2305-2310.

18. Kouadio, N. F., Kouamélan, E. P., N'douba V., Kone T., Snoeks, J. \& Ollevier, F. (2006). Update of Fish Biodiversity and Impact of Human Activities on the Community Structue, Mé River (Ivory Coast). Journal of Biological Sciences, 6(5), 805-814.

19. Kouamé, K. A., Yao, S. S., Goore Bi, G., Kouamélan E. P., N'douba, V. \& Kouassi, N. J. (2008). Influential environmental gradients and patterns of fish assemblages in a West African basin. Hydrobiologia, 603, 159-169.

20. Kouamélan, E. P., Teugels, G. G., N'douba, V., Goore Bi, G. \& Kone, T. (2003). Fish diversity and its relationships with environmental variables in a West African basin. Hydrobiologia, 505, 139-146.

21. Lande R. (1996). Statistes and partitioning of species diversity, and similarity among multiple communities. Oikos, 76, 5-13.

22. Lee, H., Beighley, R. E., Alsdorf, D., Chul Jung, H., Shum, C. K., Duan, J., Guo, J., Yamazaki, D. \& Andreadis K. (2011). "Characterization of Terrestrial Water Dynamics in the Congo Basin Using GRACE and Satellite Radar Altimetry." Remote Sensing of Environment 115(12), 3530-38.

23. Lalèyè, P. A. (2006). Length-weight and length-length relationships of fishes from the Ouémé River in Bénin (West Africa). Journal of Applied Ichthyology, 22(4), 330-333.

24. Lévêque, C. (1997). Biodiversity dynamics and conservation: the freshwater fishes of tropical Africa. Cambridge University press. 
25. Lévêque, C. \& Paugy, D. (2017a). Geographical distribution and affinities of African freshwater fishes. In D. Paugy, C. Leveque \& O. Otero (eds), The inland water fishes of Africa: Diversity, Ecology and Human use, (pp. 97-114). IRD: Paris (France), MRAC: Tervuren (Belgique).

26. Lévêque, C. \& Paugy, D. (2017b). Fish communities in river systems and associated biotopes. In D. Paugy, C. Leveque \& O. Otero (eds), The inland water fishes of Africa: Diversity, Ecology and Human use, (pp. 349-360). IRD: Paris (France), MRAC: Tervuren (Belgique).

27. Lobry, J., Gascuel, D. \& Domain, F. (2003). La biodiversité spécifique des ressources démersales du plateau continental guinéen: utilisation d'indice classique pour un diagnostic sur l'évolution des écosystèmes. Aquatic Living Resources, 16, 59-68.

28. Ludwig, J. A. \& Reynolds, J. F. (1988). Statistical Ecology: A primer on methods and computing. John Wiley \& Sons, New York.

29. Mbega, J. D. (2004). Biodiversité des poisons du basin inférieur de l'Ogooué (Gabon). Presses Universitaires de Namur.

30. Mérona, B. D. (1981). Zonation ichtyologique du bassin du Bandama (Côte d'Ivoire). Revue d'Hydrobiologie Tropicale, 14, 63-75.

31. Monsembula Iyaba, R. J. C., Liyandja, T. \& Stiassny, M. L. J. (2013). Fishes of the N'sele River (Pool Malebo, Congo basin, Central Africa): a list of species collected in the main channel and affluent tributaries, Kinshasa Province, Democratic Republic of Congo. Check List, 9, 941-956.

32. Olds, B. P., Christopher, L. J., Mark, A. R., Li Y., Evans, N. T., Turner, C. R., Deiner, K., Mahon, A. R, Brueseke M. A., Shirey P. D., Pfrender, M. E., Lodge, D. M. \& Lamberti, G. A. (2016). Estimating Species Richness Using Environmental DNA. Ecology and Evolution, 6(12), 4214-26.

33. Paugy, D. \& Benech, V. (1989). Poissons d'eau douce des bassins côtiers du Togo (Afrique de l'Ouest). Revue d'Hydrobiologie Tropicale, 22, 295-316.

34. Paugy, D. \& Lévêque, C. (2017). Impacts of human activities. In D. Paugy, C. Leveque \& O. Otero (eds), The inland water fishes of Africa: Diversity, Ecology and Human use, (pp. 459-478). IRD: Paris (France), MRAC: Tervuren (Belgique).

35. Pielou, E. C. (1966). The measurement of diversity in different types of biological collections. Journal of Theoretical Biology, 13, 131-144.

36. Pouilly, M. (1993). Habitat, écomorphologie et structure des peuplements de poissons dans trois petits cours d'eau tropicaux de Guinée. Revue d'Hydrobiologie Tropicale, 26, 319-332. 
37. Shannon C. E., 1948. A mathematical theory for communication. Bell System Technical Journal, 27: 379-423 and 623-656.

38. Snoeks, J., Harrison I. J. \& Stiassny, M. L. J. (2011). The Status and Distribution of Freshwater Fishes. In w. Darwall, K. Smith, D. Allen, R. Holland, I. Harrison \& E. Brooks (eds), The diversity of life in African freshwaters: underwater, under threat. An analysis of the status and distribution of freshwater species throughout mainland Africa, (pp. 42-87). IUCN.

39. Stiassny, M. L. J., Liyandja, T. L. D. \& Monsembula Iyaba, R. J. C. (2016). A New Small Barb (Cyprininae: Smiliogastrini) from the N'sele and Mayi Ndombe Rivers in the Lower Reaches of the Middle Congo Basin (Democratic Republic of Congo, Central Africa). American Museum Novitates, 3848: 1-16. https://doi.org/10.1206/3848.1.

40. Ter Braak, C. J. F., Šmilauer, P. (2003). Canoco 4. Cambridge university press, USA.

41. Van der Laan, R. \& Fricke, R. (2019). Eschmeyer's Catalog of Fishes: family-group names. (http://www.calacademy.org/scientists/catalogof-fishes-family-group-names/). Electronic version accessed 10 October 2019.

42. Wamuini Lunkayilakio, S., Vreven, E., Vandewalle, P., Mutambue, S. \& Snoeks, J. (2010). Contribution à la connaissance de l'ichtyofaune de l'Inkisi au Bas-Congo (RD du Congo). Cybium, 34(1), 83-91.

43. Weber-Scannell, P. K. \& Duffy, L. K. (2007). Effects of Total Dissolved Solids on Aquatic Organisms: A Review of Literature and Recommendation for Salmonid Species. American Journal of Environmental Sciences, 3 (1), 1-6.

44. Welcome, R. L. (1988). International introductions of inland aquatic species. Rome, FAO, Fish Technical Papers, 294, 318.

45. Winemiller, K. O., McIntyre, P. B., Castello, L., Fluet-Chouinard, E., Giarrizzo, T.,

Nam, S. et al. (2016). Balancing hydropower and biodiversity in the Amazon, Congo, and Mekong. Basin-scale planning is needed to minimize impacts in mega-diverse rivers. Science, 351, 128-129.

46. Yao, S.S., Kouamélan E.P., Koné T., N'douba V., Goore Bi G., Ollevier F. \& Thys Van Den Audenaerde, D. F. E. (2005). Fish communities along environment gradients within the Comoé River basin, Côte d'Ivoire. African journal of Aquatic Science, 30, 195-204. 